\title{
Bio-economic return from the green fertilizing and plant population in strip- intercropping of beet and rocket
}

\author{
Retorno bio-econômico proveniente de fertilização verde e população de plantas em consórcio em \\ faixa de beterraba e rúcula \\ Retorno bioeconómico de la fertilización verde y la población de plantas de cultivo intercalado em \\ uma franja de remolacha y rúgula
}

Received: 06/12/2021 | Reviewed: 06/22/2021 | Accept: 06/25/2021 | Published: 07/10/2021

Vitor Abel da Silva Lino

ORCID: https://orcid.org/0000-0001-5330-7928

Universidade Federal Rural do Semi-Árido, Brazil

E-mail: vabel55@gmail.com

Francisco Bezerra Neto

ORCID: https://orcid.org/0000-0001-9622-206X

Universidade Federal Rural do Semi-Árido, Brazil

E-mail: bezerra@ufersa.edu.br

Aridênia Peixoto Chaves

ORCID: https://orcid.org/0000-0002-2184-2536

Universidade Federal Rural do Semi-Árido, Brazil E-mail: aridenia.peixoto@hotmail.com

Jailma Suerda Silva de Lima

ORCID: https://orcid.org/0000-0001-7584-592X

Universidade Federal Rural do Semi-Árido, Brazil

E-mail: jailma@ufersa.edu.br

Elizangela Cabral dos Santos

ORCID: https://orcid.org/0000-0002-7074-3147

Universidade Federal Rural do Semi-Árido, Brazil E-mail: elizangelacabral@ufersa.edu.br

Renato Leandro da Costa Nunes

ORCID: https://orcid.org/0000-0001-5792-2442

Instituto Federal do Ceará, Brazil

E-mail: renatoleandro.ce@hotmail.com

Natan Medeiros Guerra

ORCID: https://orcid.org/0000-0002-4222-7102

Universidade Federal Rural do Semi-Árido, Brazil

E-mail: ntnguerra@gmail.com

Francisca Karla Kelly da Silva Lino

ORCID: https://orcid.org/0000-0003-3319-0317

Universidade Federal Rural do Semi-Árido, Brazil E-mail: karlakellysilva12@gmail.com

Jolinda Mércia de Sá

ORCID: https://orcid.org/0000-0003-4953-2641

Universidade Federal de Campina Grande, Brazil

E-mail: jolindamercia@gmail.com

Vania Christina do Nascimento Porto

ORCID: https://orcid.org/0000-0002-0352-0162

Universidade Federal Rural do Semi-Árido, Brazil

E-mail: vania@ufersa.edu.br

Rose Paula Desravines

ORCID: https://orcid.org/0000-0003-4981-9570

Universidade Federal Rural do Semi-Árido, Brazil

E-mail: rose.desravines@ alunos.ufersa.edu.br

\begin{abstract}
The triumph of the crops association with vegetables in semi-arid environment depends on crop types grown and adequate manipulation of treatment-factors tested such as fertilization, plant population, among others. Thus, this investigation aimed to valuate the bio-economic return of beet-rocket strip-intercropping in diverse balanced quantities of hairy woodrose (M. aegyptia) and roostertree (C. procera) biomass (20, 35, 50 and $65 \mathrm{t}$ ha-1 on base dry) and in different rocket plant population $(40,60,80$ and $100 \%$ of that recommended population in monocropping - RPM),
\end{abstract}


associated with the beet population of $100 \%$ of the RPM, in two years of cultivation. The bio-economic indices: land equivalent ratio (LER), intercropping advantage (IA), actual yield loss (AYL), productive efficiency index (PEI), canonical variable score $(\mathrm{Z})$, gross return $(\mathrm{GR})$ and net return $(\mathrm{NR})$, rate of return $(\mathrm{RR})$ and profit margin (PM) were assessed. The greatest bio-economic returns of beet-rocket strip-intercropping were of: $1.87 ; 7.44 ; 1.90 ; 0.98 ; 2.52$; $85,827.79$ and $65,425.01 \mathrm{R} \$$ ha-1; $4.24 \mathrm{R} \$$ for each real invested, and 77.02\%, respectively, for LER, IA, AYL, PEI, Z, GR, NR, RR and PM in the biomass quantity of $65 \mathrm{t}$ ha-1 of hairy woodrose and roostertree, in the rocket population of $100 \%$ of the RPM (a million plants ha-1). The hairy woodrose and roostertree biomass use from Caatinga biome proved to be a viable technology for growers who practice the cultivation of beet-rocket strip-intercropping in semi-arid environment.

Keywords: Hairy woodrose; Roostertree; Crop association; Agronomic plausibleness.

\section{Resumo}

O êxito da associação de culturas com hortaliças em ambiente semiárido depende do tipo de culturas cultivadas e da manipulação adequada dos fatores tratamentos testados, tais como, fertilização, população de plantas, entre outros. Assim, o objetivo deste trabalho foi avaliar o retorno bio-econômico do consórcio em faixas de beterraba e rúcula em diversas quantidades balanceadas de biomassa de jitirana (M. aegyptia) e flor-de-seda (C. procera) $(20,35,50$ e $65 \mathrm{t} \mathrm{ha}$ ${ }^{1}$ em base seca) e em diferentes populações de rúcula (40, 60, 80 e 100\% da população recomendada em monocultura PRM), associada à população de beterraba de 100\% da PRM, em dois anos de cultivos. Os índices bio-econômicos: razão equivalente de terra (RET), vantagem do consórcio (VC), perda real de rendimento (PRR), índice de eficiência produtiva (IEP), escore da variável canônica $(Z)$, retorno bruto $(\mathrm{RB})$ e retorno líquido (RL), taxa de retorno (TR) e margem de lucro (ML) foram avaliados. Os maiores retornos bio-econômicos do consórcio em faixas de beterraba e rúcula foram de: 1,$87 ; 7,44 ; 1,90 ; 0,98 ; 2,52 ; 85.827,79$ e $65.425,01 \mathrm{R} \$$ ha $^{-1} ; \mathrm{R} \$ 4,24$ para cada real investido e 77,02\%, respectivamente, para RET, VC, PRR, IEP, Z, RB, RL, TR e ML na quantidade balanceada de biomassa de $65 \mathrm{tha}{ }^{-1}$ de jitirana e flor-de-seda, na população de rúcula de $100 \%$ da PRM (um milhão de plantas ha $a^{-1}$ ). A utilização da biomassa de jitirana e flor-de-seda do bioma Caatinga mostrou-se uma tecnologia viável para os produtores que praticam o cultivo da beterraba e de rúcula em consórcio em faixas em ambiente semiárido.

Palavras-chave: Jitirana; Flor-de-seda; Consorciação de culturas; Viabilidade agronômica.

\section{Resumen}

El éxito de la asociación de cultivos con hortalizas en ambiente semiárido depende del tipo de cultivos que se cultiven y del manejo adecuado de los factores de tratamiento probados, como fertilización, población de plantas, entre otros. Así, el objetivo de este trabajo fue evaluar el retorno bioeconómico del cultivo intercalado en franjas de remolacha y rúgula en diferentes cantidades equilibradas de biomasa de campanilla (M. aegyptia) y algodón de seda $(C$. procera) $\left(20,35,50\right.$ y $65 \mathrm{t} \mathrm{ha}^{-1}$ en base seca) y en diferentes poblaciones de rúgula $(40,60,80$ y $100 \%$ de la población de monocultivo recomendada - PMR), asociada a una población de remolacha del 100\% de la PMR, en dos años de cultivo. Los índices bioeconómicos: razón equivalente de tierra (RET), ventaja del consorcio (VC), pérdida de rendimiento real (PRR), índice de eficiencia productiva (IEP), puntuación de variable canónica ( $\mathrm{Z}$ ), rendimiento bruto (RB) y rendimiento neto $(\mathrm{RN})$, tasa de rendimiento (TR) y el margen de beneficio (MB). Los mayores rendimientos bioeconómicos del cultivo intercalado de remolacha y rúgula fueron: 1,$87 ; 7,44 ; 1,90 ; 0,98 ; 2,52 ; 85.827,79$ y $65.425,01$ $\mathrm{R} \$$ ha $^{-1}$; R\$ 4.24 por cada real invertido y $77.02 \%$, respectivamente, para RET, VC, PRR, IEP, Z, RB, RN, TR y MB en la cantidad balanceada de biomasa de $65 \mathrm{t} \mathrm{ha}^{-1}$ de campanilla y algodón de seda, en la población de rúgula del $100 \%$ del PMR (un millón de plantas ha ${ }^{-1}$ ). El uso de biomasa de campanilla y algodón de seda del bioma de Caatinga demostró ser una tecnología viable para los productores que practican el cultivo de remolacha y rúgula intercalados en franjas en ambiente semiárido.

Palabras clave: Campanilla; Algodón de seda; Cultivos intercalados; Viabilidad agronómica.

\section{Introduction}

The triumph of the crops association with vegetables in semi-arid regions depends on the type of crops grown and adequate manipulation of treatment-factors tested such as fertilization, plant population, planting arrangement, among others. The beet and rocket are two healthy crops of economic, social and nutritional value, considered companions, that is, when grown together or close to each other, they meet and benefit, not only in the occupation of space, but, enabling greater use of the cultivated area, increasing soil moisture due to greater coverage and shading of the land and reducing water losses (Grangeiro et al., 2007; Meira et al., 2012).

So, intercropping companion plants such as beet tuberose and rocket leafy is an exceptional way to give greater environment biological diversity and greater crops yield per area. This type of intercrop makes possible use optimization of 
environment resources, such as nutrients, water and solar radiation, since these horticultural species have different plant sizes and growth cycles (Andrade Filho et al., 2020). Thus, companion vegetable crops do not compete for nutrients, space and light and do not have toxic (allelopathic) effects on each other.

Among the main challenges for obtaining intercropped vegetable systems of high yield and economic feasibility in semi-arid regions is the proper choice of fertilizer type. Research has shown that Caatinga biome spontaneous species, such as hairy woodrose and roostertree, have been successfully utilized as green fertilizer on intercropped vegetable systems (Sá et al., 2021; Guerra et al., 2021). These species are adapted to the edaphoclimatic conditions from the Northeast of Brazil, besides presenting high phytomass production, rapid growth and a close ratio $\mathrm{C} / \mathrm{N}$ (Batista et al., 2016).

Other factor of considerable relevance in the success of an intercropping system is the plant population, which directly influences the crops growing and development and system's productivity, through intraspecific and interspecific competition for environmental resources (Chaves et al., 2020). Studies on plant populations in crop associations are generally designed in part to improve system productivity and provide a rationalization of necessary crop treatments. However, crops increase their productivity to a certain density, after which the limit is reached, and competition for area and nutrients play an relevant role, resulting in reduced photosynthetic rates and nutrient concentrations, with potential negative consequences for plant growth and crops productivity, as also for the products quality (Strassburger et al., 2010; Ribeiro et al., 2017).

Investigation performed in the attempt to recommend intercropping systems with companion cultures suggest that these systems should be evaluated through bio-economic indices in function of production factors tested in the study to indicate or not their bio-economic feasibility. Among these used indices are: land equivalent ratio (Silva et al., 2018a), actual yield loss (Cecilio Filho et al., 2015), intercropping advantage (Gebru, 2015), productive efficiency index (Bezerra Neto et al., 2010), canonical variable score (Silva et al., 2021), crops aggressivity (Cecílio Filho et al., 2015), competitive ratio (Pinto et al., 2011), gross and net returns (GI and NI), rate of return, and profit margin (Silva et al., 2017). Investigation with rocket, carrot and lettuce polyculture associated in strips under different hairy woodrose quantities in diverse plant populations of the crops showed greater viability and bio-economic return of the polyculture when $25 \mathrm{t} \mathrm{ha}^{-1}$ of the green fertilizer was added to the soil in the population of rocket (R), carrot $(\mathrm{C})$ and lettuce (L) of 50R-50C-50L\% of the recommended population in monocropping (Oliveira et al., 2017).

Thus, this investigation aimed to valuate the bio-economic return of beet-rocket strip-intercropping in diverse balanced quantities of hairy woodrose and roostertree biomass and in different rocket plant population in two years of cultivation.

\section{Methodology}

The methodology for carrying out the experimental procedures, using materials and handling the field experiments of the beet and rocket intercropping followed those established by Silva et al. (2018a, b) and Sousa et al. (2018). For the statistical design of the field experiments, the methodology recommended by Bhatt (2011) was followed.

\subsection{Locations, climate and soils}

The field experiments were performed in the Experimental Farm of Universidade Federal Rural do Semi-Árido

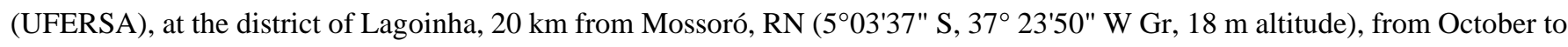
December of 2018 and from September to November of 2019. The region climate is 'BShw', dry and very hot, with a dry season, which occurs from June to January, and a rainy season, from February to May (Alvares et al., 2014). In the years of 2018 and 2019 , the mean temperatures were 28.18 and $26.79^{\circ} \mathrm{C}$, the mean relative air humidity was 66.74 and $67.39 \%$, respectively. There was no record of rainfall in both experimental periods (INMET, 2019). The minimum and maximum temperatures and relative humidity in each year of cultivation are showed in Figure 1. 
Figure 1. Temperatures and relative humidity data in the years of cultivation of 2018 and 2019.
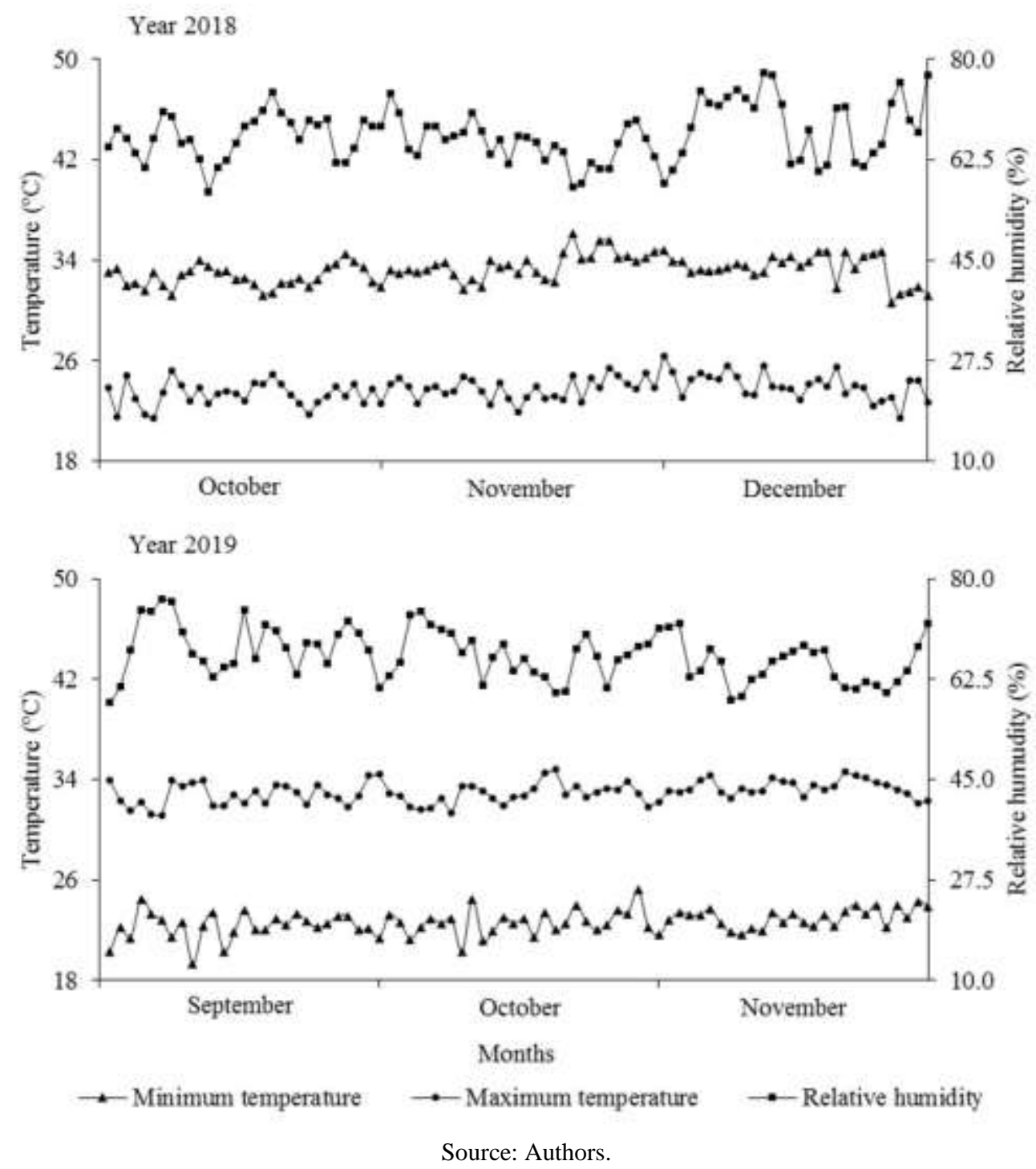

The soils of planted areas were classified as distrophic Red-Yellow Argisol with a sandy-loam texture (Santos et al., 2018). The chemical analyses results of these soils were: $\mathrm{pH}$ (water) $=8.10 ; \mathrm{EC}=0.24 \mathrm{dS} \mathrm{m}^{-1} ; \mathrm{O} . \mathrm{M}=4.97 \mathrm{~g} \mathrm{~kg}^{-1} ; \mathrm{N}=0.35 \mathrm{~g}$ $\mathrm{kg}^{-1} ; \mathrm{P}=22.80 \mathrm{mg} \mathrm{dm}^{-3} ; \mathrm{K}=64.70 \mathrm{mg} \mathrm{dm}{ }^{-3} ; \mathrm{Ca}=3.28 \mathrm{cmol}_{\mathrm{c}} \mathrm{dm}^{-3} ; \mathrm{Mg}=0.78 \mathrm{cmol}_{\mathrm{c}} \mathrm{dm}^{-3} ; \mathrm{Na}=32.70 \mathrm{mg} \mathrm{dm}{ }^{-3} ; \mathrm{Cu}=0.10 \mathrm{mg}$ $\mathrm{dm}^{-3} ; \mathrm{Fe}=1.91 \mathrm{mg} \mathrm{dm}^{-3} ; \mathrm{Mn}=11.67 \mathrm{mg} \mathrm{dm}^{-3} ; \mathrm{Zn}=2.63 \mathrm{mg} \mathrm{dm}^{-3}$, in the year of 2018 . In the year of 2019, the results were: $\mathrm{pH}($ water $)=7.10 ; \mathrm{EC}=0.10 \mathrm{dS} \mathrm{m}{ }^{-1} ; \mathrm{O} . \mathrm{M} .=5.27 \mathrm{~g} \mathrm{~kg}^{-1} ; \mathrm{N}=0.28 \mathrm{~g} \mathrm{~kg}^{-1} ; \mathrm{P}=22.00 \mathrm{mg} \mathrm{dm}^{-3} ; \mathrm{K}=69.47 \mathrm{mg} \mathrm{dm}^{-3} ; \mathrm{Ca}^{2}=2.70$ $\mathrm{cmol}_{\mathrm{c}} \mathrm{dm}^{-3} ; \mathrm{Mg}=0.50 \mathrm{cmol}_{\mathrm{c}} \mathrm{dm}^{-3} ; \mathrm{Na}=26.70 \mathrm{mg} \mathrm{dm}^{-3} ; \mathrm{Cu}=0.24 \mathrm{mg} \mathrm{dm}^{-3} ; \mathrm{Fe}=2.71 \mathrm{mg} \mathrm{dm}^{-3} ; \mathrm{Mn}=12.17 \mathrm{mg} \mathrm{dm}^{-3} ; \mathrm{Zn}=5.27$ $\mathrm{mg} \mathrm{dm}{ }^{-3}$.

\subsection{Experimental design and treatments}

An experiment factorial $4 \times 4$ with 4 replications was designed in random blocks in this research, with the first treatmentfactor composed by balanced quantities of hairy woodrose and roostertree biomass (20, 35, 50 and $65 \mathrm{t} \mathrm{ha}^{-1}$ on base dry) and the second treatment-factor by the rocket populations (40, 60, 80 and 100\% of the recommended density for monocropping - RPM). The recommended populations for beet and rocket monocroppings are 500 and 1,000 thousand plants ha ${ }^{-1}$, respectively, in the region (Silva et al., 2011; Lima et al., 2014). Monocropping plots of beet and rocket were planted and fertilized with balanced 
quantities of hairy woodrose and roostertree biomass optimized by the research to obtain the bio-economic indices for the intercropped systems.

The beet-rocket intercrop was performed in alternated strips with $50 \%$ of the area cultivated with beet and $50 \%$ cultivated with rocket. In the experimental plots, the alternating strips were composed by four rows, flanked by two rocket rows on one side and two beet rows on the other side (Figure 2). Total area for each plot was $2.88 \mathrm{~m}^{2}(2.40 \times 1.20 \mathrm{~m})$, with usable area of $1.60 \mathrm{~m}^{2}(1.60 \times 1.00 \mathrm{~m})$. This usable area was composed by two central strips of plants, with the first and the last plant of each row excluded of the strips.

Figure 2. Plots detail for beet cropping in the population of 500 thousand plants $\mathrm{ha}^{-1}$ intercropped with the rocket in the populations of 40 (A), 60 (B), 80 (C) and $100 \%$ (D) of the RPM.
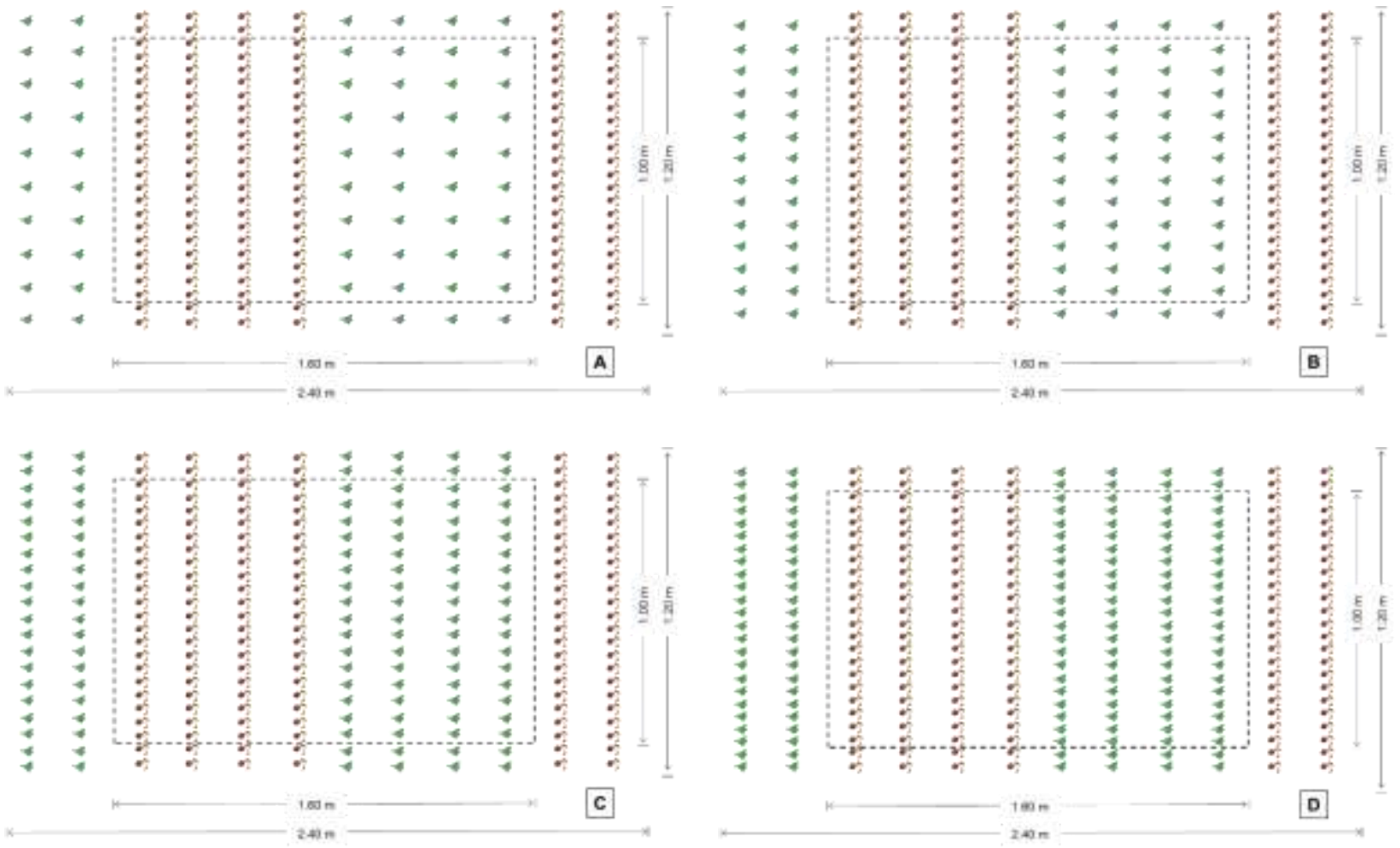

Source: Authors

Vegetable monocroppings were sowed in six rows each, in a total area of $1.44 \mathrm{~m}^{2}(1.20 \times 1.20 \mathrm{~m})$, with usable area of $0.80 \mathrm{~m}^{2}(0.80 \times 1.00 \mathrm{~m})$. The beet was planted in the spacing of $0.20 \times 0.10 \mathrm{~m}$ and the rocket in the spacing of $0.20 \times 0.05 \mathrm{~m}$. The usable area was composed by the four rows of central plants, with the first and the last plant of each row excluded (Figure $3)$. 
Figure 3. Plots detail for monocroppings at the populations of 500 (A) and 1000 (B) thousand plants per hectare for the beet and rocket cultures.
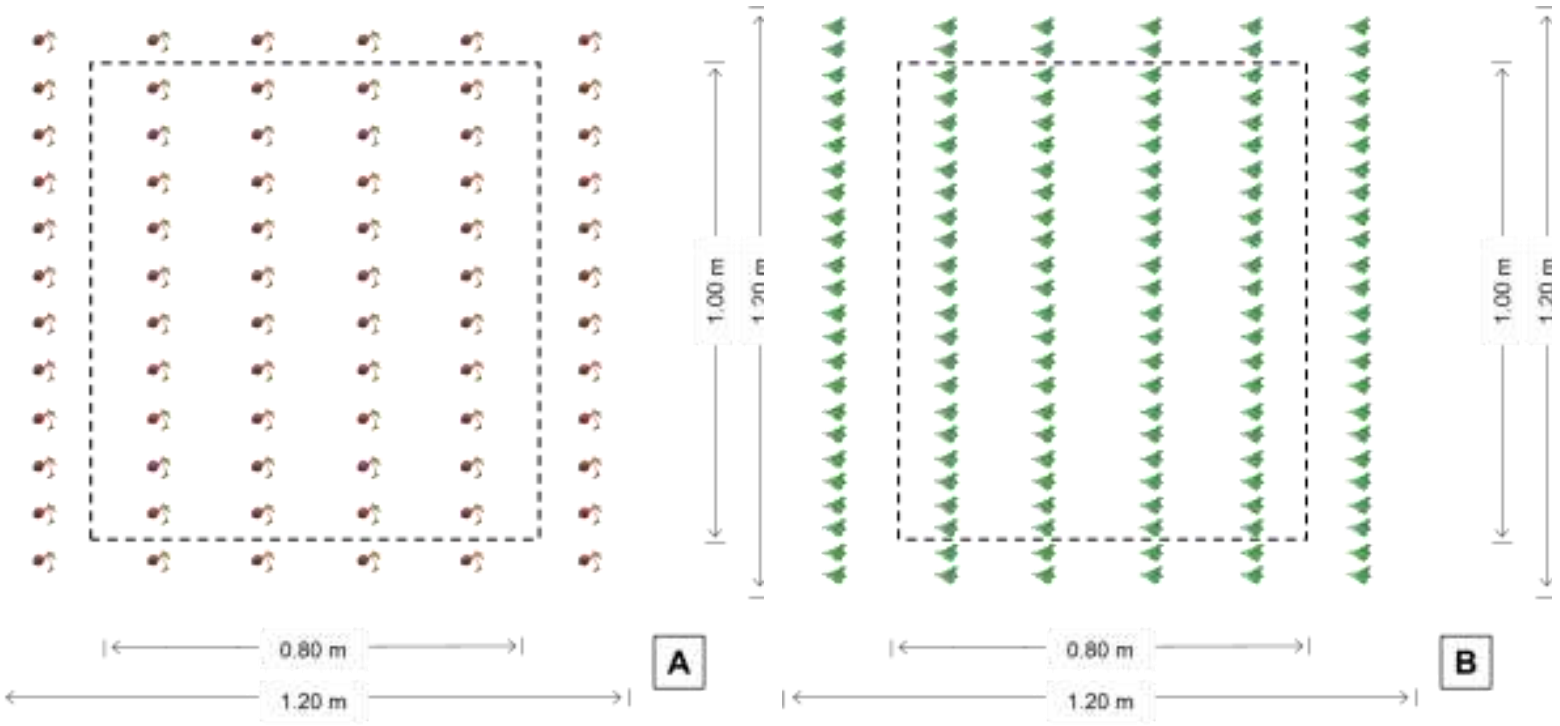

Source: Authors

The single crops of beet and rocket are of capital importance in the assessing of the bio-economic indices of the associated systems. The spacings for beet and rocket plants in intercropping and in monocropping are presented in Table 1.

Table 1. Details for beet and rocket populations in intercropping and in monocropping with their respective spacings.

\begin{tabular}{|c|c|c|c|}
\hline \multicolumn{2}{|c|}{$\begin{array}{l}\text { Populations for intercropped crops } \\
\text { (thousand plants ha-1) }\end{array}$} & \multicolumn{2}{|c|}{ Spacings (m) } \\
\hline Beet & Rocket & $\begin{array}{c}\text { Beet } \\
\text { (1 plant per hole })\end{array}$ & $\begin{array}{c}\text { Rocket } \\
\text { (2 plants per hole) }\end{array}$ \\
\hline 500 & $400 \quad(40 \%$ RDSC $)$ & $0.20 \times 0.05$ & $0.20 \times 0.120$ \\
\hline 500 & $600 \quad(60 \%$ RDSC $)$ & $0.20 \times 0.05$ & $0.20 \times 0.085$ \\
\hline 500 & $800 \quad(80 \%$ RDSC $)$ & $0.20 \times 0.05$ & $0.20 \times 0.062$ \\
\hline 500 & 1000 (100\% RDSC) & $0.20 \times 0.05$ & $0.20 \times 0.050$ \\
\hline \multicolumn{2}{|c|}{$\begin{array}{l}\text { Recommended population for monocropping - RPM } \\
\text { (thousand plants } \mathrm{ha}^{-1} \text { ) }\end{array}$} & & (1 plant per hole) \\
\hline Beet & $500(100 \%$ RDSC $)$ & $0.20 \times 0.10$ & \\
\hline Rocket & 1000 (100\% RDSC) & & $0.20 \times 0.20$ \\
\hline
\end{tabular}

Source: Authors

\subsection{Experiments conducting and materials}

Soil preparation consisted of plowing and harrowing, followed by lifting the beds with a tractor with a bed former. After soil preparation, area solarization was made for 30 days before planting with a $30 \mu \mathrm{m}$ transparent plastic (Vulca Brilho Bril Fles) following the methodology recommended by Silva et al. (2006), to reducing the population of phytopathogenic organisms present in the soil which could potentially harm crop productivity.

The materials used as green fertilizers were the hairy woodrose and roostertree, collected from native vegetation in several rural areas of Mossoró, RN, before the beginning of flowering. After collections, the plants were crushed into fragments of two to three centimeters, which were dehydrated at room temperature until reaching a moisture content of $10 \%$ and then 
subjected to laboratory analysis, whose chemical compositions obtained were in 2018: $\mathrm{N}=11.40 \mathrm{~g} \mathrm{~kg}^{-1} ; \mathrm{P}=2.36 \mathrm{~g} \mathrm{~kg}^{-1} ; \mathrm{K}^{2}$ $2.20 \mathrm{~g} \mathrm{~kg}^{-1} ; \mathrm{Mg}=9.75 \mathrm{~g} \mathrm{~kg}^{-1}$ and $\mathrm{Ca}=8.30 \mathrm{~g} \mathrm{~kg}^{-1}$ for hairy woodrose, and $\mathrm{N}=18.40 \mathrm{~g} \mathrm{~kg}^{-1} ; \mathrm{P}=3.14 \mathrm{~g} \mathrm{~kg}^{-1} ; \mathrm{K}=4.50 \mathrm{~g} \mathrm{~kg}^{-1} ; \mathrm{Mg}$ $=13.35 \mathrm{~g} \mathrm{~kg}^{-1}$ and $\mathrm{Ca}=16.30 \mathrm{~g} \mathrm{~kg}^{-1}$ for roostertree. In 2019: $\mathrm{N}=16.60 \mathrm{~g} \mathrm{~kg}^{-1} ; \mathrm{P}=2.79 \mathrm{~g} \mathrm{~kg}^{-1} ; \mathrm{K}=47.80 \mathrm{~g} \mathrm{~kg}^{-1} ; \mathrm{Mg}=7.07 \mathrm{~g}$ $\mathrm{kg}^{-1}$ and $\mathrm{Ca}=19.35 \mathrm{~g} \mathrm{~kg}^{-1}$ for hairy woodrose, and $\mathrm{N}=21.90 \mathrm{~g} \mathrm{~kg}^{-1} ; \mathrm{P}=1.92 \mathrm{~g} \mathrm{~kg}^{-1} ; \mathrm{K}=20.90 \mathrm{~g} \mathrm{~kg}^{-1} ; \mathrm{Mg}=9.22 \mathrm{~g} \mathrm{~kg}^{-1}$ and Ca $=17.00 \mathrm{~g} \mathrm{~kg}^{-1}$ for roostertree.

The beet 'Early Wonder' and rocket 'Cultivada' cultivars were sown in October in the first cultivation, and in November in the second rocket cultivation in the year of 2018. In the year of 2019, both cultivars were sown in September in the first cultivation and in October in the second rocket cropping, in $3 \mathrm{~cm}$ deep holes, with three to four seeds per hole, and covered with commercial substrate. After thinning, two plants per hole for rocket and one plant per hole for beet were left in the intercrops. In the monocrops, only one plant per hole for both crops.

The irrigations in the experiments were performed daily by a micro sprinkler irrigation system, in two applications (morning and afternoon). The water amount supplied was determined from the beet crop coefficients (average Kc: 0.83) (Oliveira Neto et al., 2011), with irrigation depth, when necessary, of $8 \mathrm{~mm} \mathrm{day}^{-1}$. Weed control was performed whenever necessary, manually removing the plants. No chemical method for pest or disease control was needed.

The rocket and beet harvests in the two years of cultivation were performed at 30 and 70 after planting (DAP), followed by evaluations.

\subsection{Evaluated variables}

The crops characteristics assessed in the intercropping systems were beet roots commercial productivity, determined by plant roots fresh mass of the usable area in large, extra AA, extra A and extra, expressed in $\mathrm{t} \mathrm{ha}^{-1}$, and the rocket green mass yield determined by the leaves fresh mass of plants in the usable area, expressed in $\mathrm{tha}^{-1}$. The bio-economic efficiency for the intercropping systems of beet and rocket was obtained through the following indices:

a) The land equivalent ratio (LER) was calculated by the formula (Silva et al., 2018a): LER $=Y_{b r} / Y_{b}+Y_{b r} / Y_{b}+$ $\mathrm{Y}_{\mathrm{r} 1 \mathrm{~b}} / \mathrm{Y}_{\mathrm{r} 1}+\mathrm{Y}_{\mathrm{r} 2 \mathrm{~b}} / \mathrm{Y}_{\mathrm{r} 2}$, where $\mathrm{Y}_{\mathrm{br} 1}$ e $\mathrm{Y}_{\mathrm{br} 2}$ represents the beet productivity in intercrop with rocket in the first and second cultivation; $\mathrm{Y}_{\mathrm{b}}$ is the beet productivity in monocrop; $\mathrm{Y}_{\mathrm{r} 1 \mathrm{~b}}$ and $\mathrm{Y}_{\mathrm{r} 2 \mathrm{~b}}$ are green mass yields of rocket in intercrop with beet in the first and second cultivation; $\mathrm{Y}_{\mathrm{r} 1}$ and $\mathrm{Y}_{\mathrm{r} 2}$ are rocket green mass yields in monocrop in the first and second cultivation. This biological index is defined as the relative area of land under monocrop conditions, which is required to provide the yields obtained in intercrop. When values of LER $>1$, the intercrop favors crop growth and yield or when values of LER $<1$, the intercrop negatively affects crop growth and yield.

b) The actual yield loss (AYL) was calculated by the formula (Cecilio Filho et al., 2015): AYL $=A Y L b+A Y L_{r} ; A Y L_{b}$ $=\left[\left\{\left(\mathrm{Y}_{\mathrm{bb}} / \mathrm{Z}_{\mathrm{br}}\right) /\left(\mathrm{Y}_{\mathrm{b}} / \mathrm{Z}_{\mathrm{bb}}\right)\right\}-1\right]$ e $A Y L_{\mathrm{r}}=\left[\left\{\left(\mathrm{Y}_{\mathrm{rb}} / \mathrm{Z}_{\mathrm{rb}}\right) /\left(\mathrm{Y}_{\mathrm{rr}} / \mathrm{Z}_{\mathrm{rr}}\right)\right\}-1\right]$, where $A \mathrm{YL}_{\mathrm{b}}$ e $A \mathrm{AL}_{\mathrm{r}}$ are actual yield losses for beet and rocket; $\mathrm{Y}_{\mathrm{rb}}$, green mass yield of rocket in intercrop with beet and $\mathrm{Y}_{\mathrm{br}}$ the beet roots commercial productivity in intercrop with rocket; $\mathrm{Y}_{\mathrm{rr}}$, green mass yield of rocket in monocrop and $\mathrm{Y}_{\mathrm{bb}}$ the beet roots commercial productivity in monocrop; $\mathrm{Z}_{\mathrm{bb}}$ and $\mathrm{Z}_{\mathrm{rr}}$, the proportions of beet and rocket in monocrop; $\mathrm{Z}_{\mathrm{br}}$ and $\mathrm{Z}_{\mathrm{rb}}$, the proportions of beet in intercrop with rocket and rocket with beet. If $\mathrm{AYL}>0$, there is an accumulated advantage in the intercrop compared to monocrop, if $\mathrm{AYL}<0$, there is a disadvantage in the intercrop.

c) The intercropping advantage (AI) was calculated by the formula (Gebru, 2015): $\mathrm{IA}=\mathrm{IA}_{\mathrm{b}}+\mathrm{IA}_{\mathrm{r}}$, where $\mathrm{IA}_{\mathrm{b}}$ is the partial advantage in favor of beet-rocket intercropping; $\mathrm{IA}_{\mathrm{r}}$ the partial advantage for rocket-beet intercropping; $\mathrm{IA}_{b}=\mathrm{AYL}_{b} \times \mathrm{P}_{b}$ and $I A_{r}=A Y L_{r} \times P_{r}$, where $A Y L_{b}$ and $A Y L_{r}$ are described in AYL. $P_{b}$ is the price for beet in $R \$ k^{-1}$ and $P_{r}$ the price for rocket in $\mathrm{R} \$ \mathrm{~kg}^{-1}$. The mean prices paid to the producer by beet and rocket in December 2019 were $1.64 \mathrm{R} \$ \mathrm{~kg}^{-1}$ and $5.18 \mathrm{R} \mathrm{kg}^{-1}$, respectively. 
d) The productive efficiency index (PEI) was calculated by DEA (Data Envelopment Analysis) model with constant returns to scale (Bezerra Neto et al., 2010), since there is no evidence of significant differences in scale. The mathematical formulation of the model is: $\operatorname{Maxz}=\sum_{\mathrm{j}=1}^{\mathrm{r}} \mu_{\mathrm{j}} \mathrm{x}_{\mathrm{jo}}$, subject to $\sum_{\mathrm{i}=1}^{\mathrm{S}} v_{\mathrm{i}} \mathrm{w}_{\mathrm{io}}=1 ; \sum_{\mathrm{j}=1}^{\mathrm{r}} \mu_{\mathrm{j}} \mathrm{x}_{\mathrm{jk}}-\sum_{\mathrm{i}=1}^{\mathrm{s}} v_{\mathrm{i}} \mathrm{w}_{\mathrm{ik}} \leq 0, \mathrm{k}=1$.. $\mathrm{n} ; \mu_{\mathrm{j}}, v_{\mathrm{i}} \geq 0, \mathrm{i}=1 \ldots \mathrm{s}, \mathrm{j}=1 \ldots \mathrm{r}$, where wik: input value $\mathrm{i}(\mathrm{i}=1 \ldots \mathrm{s})$, for the treatment $\mathrm{k}(\mathrm{k}=1 \ldots \mathrm{n})$; yjk: value of output $\mathrm{j}(\mathrm{j}=$ $1 \ldots \mathrm{r}$ ), for the treatment $\mathrm{k}$; $v \mathrm{i}$ and $\mu \mathrm{j}$ : weights attributed to inputs and outputs, respectively; o: treatment under analysis.

The intercrops (treatments) were the evaluation units. As outputs, the rocket green mass yields in the first and second cropping and the beet roots commercial productivity were used. As input, it was used the rate of return.

e) The intercropping efficiency was also assessed by the score of the canonical variable Z (Silva et al., 2021), obtained through the bivariate analysis of the variance of the beet commercial productivity and rocket green mass yield.

f) Aggressivity was another biological index used to indicate how much the relative increase in production of a component $b$ crop (in this case, beet) is greater than that of a component a crop (rocket) in an intercropped system. This index was determined by the expressions (Cecílio Filho et al., 2015): $A_{\mathrm{rb}}=\left(\mathrm{Y}_{\mathrm{rb}} / \mathrm{Y}_{\mathrm{rr}} \times \mathrm{Z}_{\mathrm{rb}}\right)-\left(\mathrm{Y}_{\mathrm{br}} / \mathrm{Y}_{\mathrm{bb}} \times \mathrm{Z}_{\mathrm{br}}\right)$ e $A_{\mathrm{br}}=\left(\mathrm{Y}_{\mathrm{br}} / \mathrm{Y}_{\mathrm{bb}} \times \mathrm{Z}_{\mathrm{br}}\right)$ $\left(Y_{\mathrm{rb}} / \mathrm{Y}_{\mathrm{rr}} \times \mathrm{Z}_{\mathrm{rb}}\right)$, where $A_{\mathrm{rb}}$ is the aggressiveness of rocket over the beet and $A_{b r}$ is the aggressiveness of the beet over the rocket. The definitions of the terms of the expressions are presented above. If the value of $\mathrm{A}$ is equal to zero, both crops in the intercropping are equally competitive. If $\mathrm{A}$ is positive, then the component culture with a positive sign is dominant and the one with a negative sign is dominated.

g) The competitive ratio (CR) was used to measure the degree of competition of one crop over another. This index indicates how many times one component is more competitive than another (Pinto et al., 2011). It was calculated by the expression: $\mathrm{CR}=\mathrm{CR}_{\mathrm{b}}+\mathrm{CR}_{\mathrm{r}}$, where $\mathrm{CR}_{\mathrm{b}}=\left[\left(\mathrm{Y}_{\mathrm{br}} / \mathrm{Y}_{\mathrm{bb}}\right) /\left(\mathrm{Y}_{\mathrm{rb}} / \mathrm{Y}_{\mathrm{rr}}\right)\right] \times\left(\mathrm{Z}_{\mathrm{rb}} / \mathrm{Z}_{\mathrm{br}}\right)$ e $\mathrm{CR}_{\mathrm{r}}=\left[\left(\mathrm{Y}_{\mathrm{rb}} / \mathrm{Y}_{\mathrm{rr}}\right) /\left(\mathrm{Y}_{\mathrm{br}} / \mathrm{Y}_{\mathrm{bb}}\right)\right] \times\left(\mathrm{Z}_{\mathrm{br}} / \mathrm{Z}_{\mathrm{rb}}\right) . \mathrm{CR}_{\mathrm{b}}$ and $\mathrm{CR}_{\mathrm{r}}$ are the competitive ratios for beet and rocket. In the intercrop, the crop with the highest CR has a greater capacity to use ambient resources as compared to the other component crop.

h) Gross return (GR) was determined by the product of crops productivities per hectare by the price paid to the producer, in December 2019. The average prices paid were $\mathrm{R} \$ 1.64 \mathrm{~kg}^{-1}$ for beet and $\mathrm{R} \$ 5.18 \mathrm{~kg}^{-1}$ for rocket.

The total production costs (TC) of the intercropping systems were determined at the end of each production cycle, through an ex-post cost analysis (Silva et al., 2015). It represents the total expenditure per hectare of cultivated area, which includes the services provided by stable capital.

i) Net return (NR) was calculated by discounting the total production costs (TC) from gross income (GR) per hectare.

j) The rate of return (RR) was expressed by formula: $R R=G R / T C$, corresponding to how many reais are obtained for each real invested in the intercrop.

k) The profit margin (PM) was calculated by the formula (Silva et al., 2017): PM (\%) = (NR/GR) x 100.

\subsection{Statistical analysis}

For each year was performed a univariate analysis of variance for all indices evaluated through SISVAR software (Ferreira, 2011). Because of the variances homogeneity between the years of cultivation, a mean was calculated between these years for each treatment. Posteriorly, a regression analysis was made in each index, and then a response surface was adjusted in function of balanced quantities of hairy woodrose and roostertree biomass and rocket plant populations, using the Table Curve 3D software (Systat Software, 2021). 


\section{Results and Discussion}

\subsection{Biological indexes}

For the biological indices: land equivalent ratio (LER), actual yield loss (AYL), productive efficiency index (PEI), score of the canonical variable (Z), aggressivity (A) of cultures and competitive ratio (CR) were not recorded no significant interaction among the treatment-factors. On the other hand, for the indice intercropping advantage (IA), a significant interaction was observed between the treatment-factors (Table 2).

Table 2. F values for land equivalent ratio (LER), intercropping advantage (IA), actual yield loss (AYL), productive efficiency index (PEI), score of canonical variable $(\mathrm{Z})$, aggressivity of beet over rocket $\left(\mathrm{A}_{\mathrm{b}}\right)$, aggressivity of rocket over beet $\left(\mathrm{A}_{\mathrm{r}}\right)$ and competitive ratio $(\mathrm{CR})$ for beet-rocket intercropping under balanced quantities of hairy woodrose and roostertree biomass and rocket plant populations.

\begin{tabular}{|c|c|c|c|c|c|c|c|c|c|}
\hline Sources of variation & $\mathrm{DF}$ & LER & IA & AYL & PEI & $\mathrm{Z}$ & $A_{b}$ & $A_{r}$ & CR \\
\hline Blocks & 3 & $0.77^{\mathrm{ns}}$ & $1.12^{\mathrm{ns}}$ & $1.30^{\mathrm{ns}}$ & $1.00^{\mathrm{ns}}$ & $0.76^{\mathrm{ns}}$ & $1.44^{\mathrm{ns}}$ & $1.44^{\mathrm{ns}}$ & $3.94^{* *}$ \\
\hline $\begin{array}{l}\text { Quantities of hairy woodrose and } \\
\text { roostertree biomass (Q) }\end{array}$ & 3 & $17.58^{* *}$ & $30.42^{* *}$ & $17.63^{* *}$ & $3.00^{*}$ & $31.48^{* *}$ & $6.17^{* *}$ & $6.17^{* *}$ & $2.49^{\text {ns }}$ \\
\hline Rocket population $(\mathrm{P})$ & 3 & $97.05^{* *}$ & $114.71^{* *}$ & $98.73^{* *}$ & $131.02^{* *}$ & $112.35^{* *}$ & $23.57^{* *}$ & $23.57^{* *}$ & $5.15^{* *}$ \\
\hline $\mathrm{Q} \times \mathrm{P}$ & 9 & $1.40^{\mathrm{ns}}$ & $2.66^{* *}$ & $1.66^{\mathrm{ns}}$ & $1.25^{\mathrm{ns}}$ & $2.12^{\mathrm{ns}}$ & $1.20^{\mathrm{ns}}$ & $1.20^{\mathrm{ns}}$ & $0.44^{\mathrm{ns}}$ \\
\hline $\mathrm{CV}(\%)$ & & 7.73 & 20.98 & 21.30 & 3.22 & 8.11 & 25.35 & -25.35 & 3.38 \\
\hline
\end{tabular}

$* *=\mathrm{P}<0.01 ; *=\mathrm{P}<0.05 ; \mathrm{ns}=\mathrm{P}>0.05$. Source: Authors.

Nevertheless, response surfaces were adjusted for LER, IA, AYL, PEI and Z in function of treatment-factors, showing the highest values of $1.87 ; 7.44 ; 1.90 ; 0.98$ and 2.52 in these indices in the combination of biomass balanced quantity of $65 \mathrm{tha}$ ${ }^{1}$ of the fertilizers with the rocket population of $100 \%$ of the RPM, corresponding to 1000 thousand plants ha ${ }^{-1}$ (Figure 4). The biological effectiveness of the beet-rocket intercropping explicitly highlighted in these indices values, shows the superiority of the intercropping over monocroppings, indicating an ideal complementarity and competitiveness between the crops, thus evidencing a better use of ambient resources. 
Figure 4. Land equivalent ratio (A), intercropping advantage (B), actual yield loss (C), productive efficiency index (D), and score of the canonical variable $\mathrm{Z}$ (E) for beet-rocket intercropping under balanced quantities of hairy woodrose and roostertree biomass and rocket plant populations.

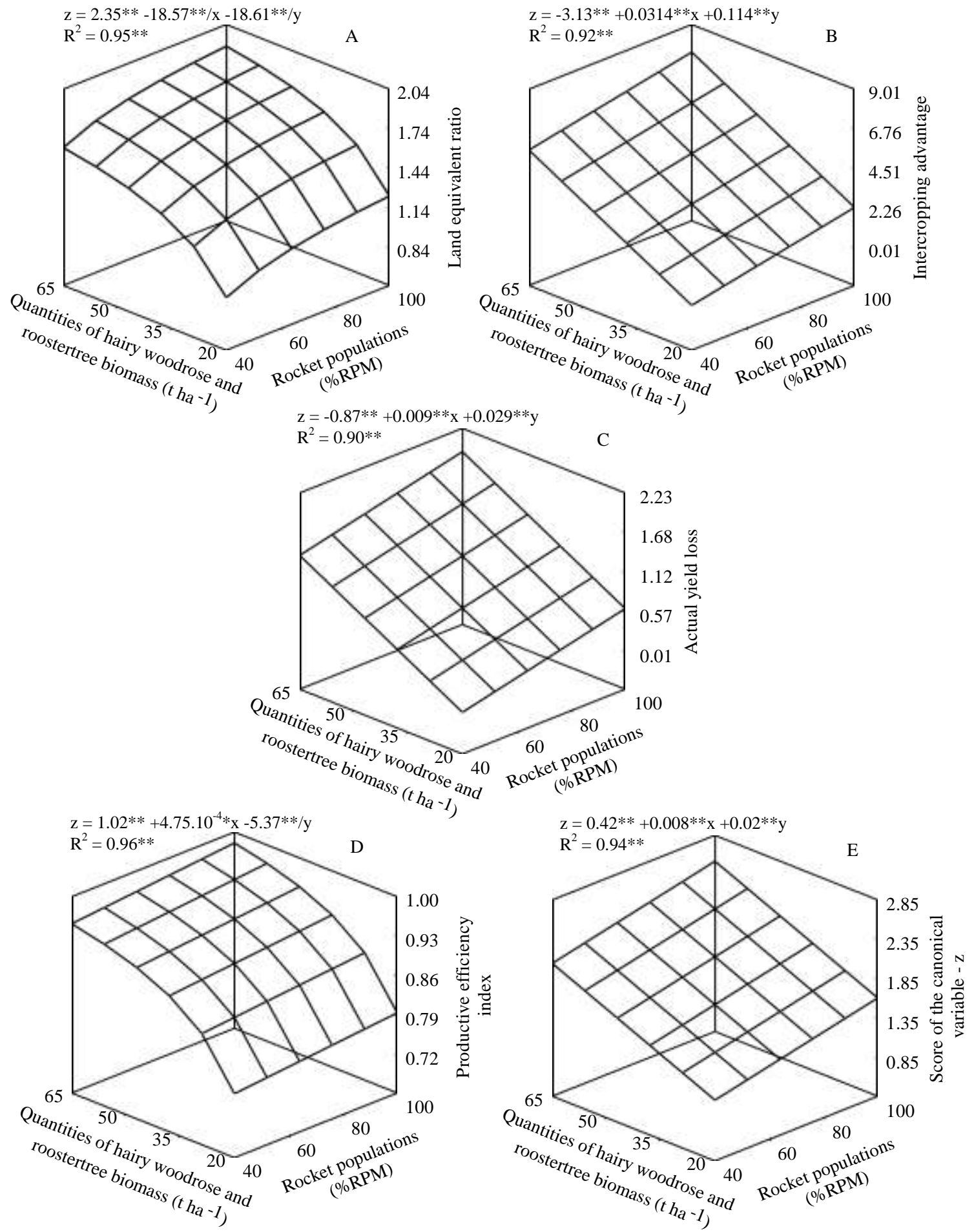

Source: Authors.

The chemical, physical and biological improvement of the soil proportionated by the quantities of green fertilizers made it possible to reach the maximum biological effectiveness of intercropping systems. Green fertilizer, besides providing the nutrients necessary for crops development, increases the content of soil organic matter and nutrient availability, reduces erosion 
levels and increases the permeability and activity of soil microbiota and reduces the competition levels between crops (Graham \& Haynes, 2006).

The intercropping advantage of beet and rocket can be observed by LER and AYL indices. When values of LER > 1, this is indicative of a superiority of the associated system with regard to the use of ambient resources as compared to monocropping (Oseni, 2010). It means that there was a gradual growth in the resources use with the increase in the quantities of green fertilizers and in the rocket population, expressed by LER $>1$ values. The increase in rocket population positively influenced the interspecific competition of beet and rocket crops, as a result a more advantageous intercrop than monocrop, and also highlighted by AYL value much higher than 1. It is relevant to emphasize that the AYL value provides very precise information regarding competition between component crops in the intercropped system, both intraspecific and interspecific (Dhima et al., 2007).

A challenge of leafy and tuberous vegetables intercropping is to recognize if there is a biological advantage in this association. Sá et al. (2021) associating rocket with radish in strip-intercropping in semi-arid ambient fertilized with hairy woodrose and roostertree under various rocket populations, obtained the highest biological indices, LER (1.64), IA (5.16), AYL (1.31), PEI (0.86) and Z (1.54) in the rocket population of $100 \%$ of the RPM fertilized with $65 \mathrm{t} \mathrm{ha}^{-1}$ of green fertilizers biomass incorporated to the soil. These values reached in this intercropping system corroborate with those obtained in this investigation, thus demonstrating that the association of quantities of the green fertilizers with planting population of the tested cultures is of great usefulness in the efficient use of ambient resources, resulting in practice advantage of intercropping system of tuberous crops with leafy crops.

The aggressivity of beet $\left(A_{b}\right)$ over the rocket had a maximum value of 0.56 also in the biomass balanced quantity of 65 $\mathrm{t} \mathrm{ha}^{-1}$ of green fertilizers and the rocket population of $100 \%$ of the RPM, while the rocket aggressivity $\left(\mathrm{A}_{\mathrm{r}}\right)$ over the beet, the maximum value reached was -0.25 in the biomass balanced quantity of $20 \mathrm{t} \mathrm{ha}^{-1}$ of the green fertilizers with the rocket population of 100\% of the RPM (Figures 5A and 5B). Based on these results, it can be observed that beet was the dominant crop and rocket was the dominated crop in associated system. This index is indicative of the complementarity degree between the component crops, as it dictates the intraspecific and interspecific competition between crops in the associated system. These results differ from those reported by Sá et al. (2021), when they got a radish aggressivity over rocket of 0.19 in the biomass balanced quantity of $20 \mathrm{tha}^{-1}$ of the green fertilizers with the rocket population of $40 \%$ of the RPM, and a rocket aggressivity over radish of -0.03 in the biomass balanced quantity of $65 \mathrm{tha}^{-1}$ of the green fertilizers and rocket population of $100 \%$ of the RPM. These differences are probably related to the type of tuberose planted. 
Figure 5. Beet aggressivity (A), rocket aggressivity (B) and competitive ratio (C) of the beet and rocket intercropping under balanced quantities of hairy woodrose and roostertree biomass and rocket plant populations.

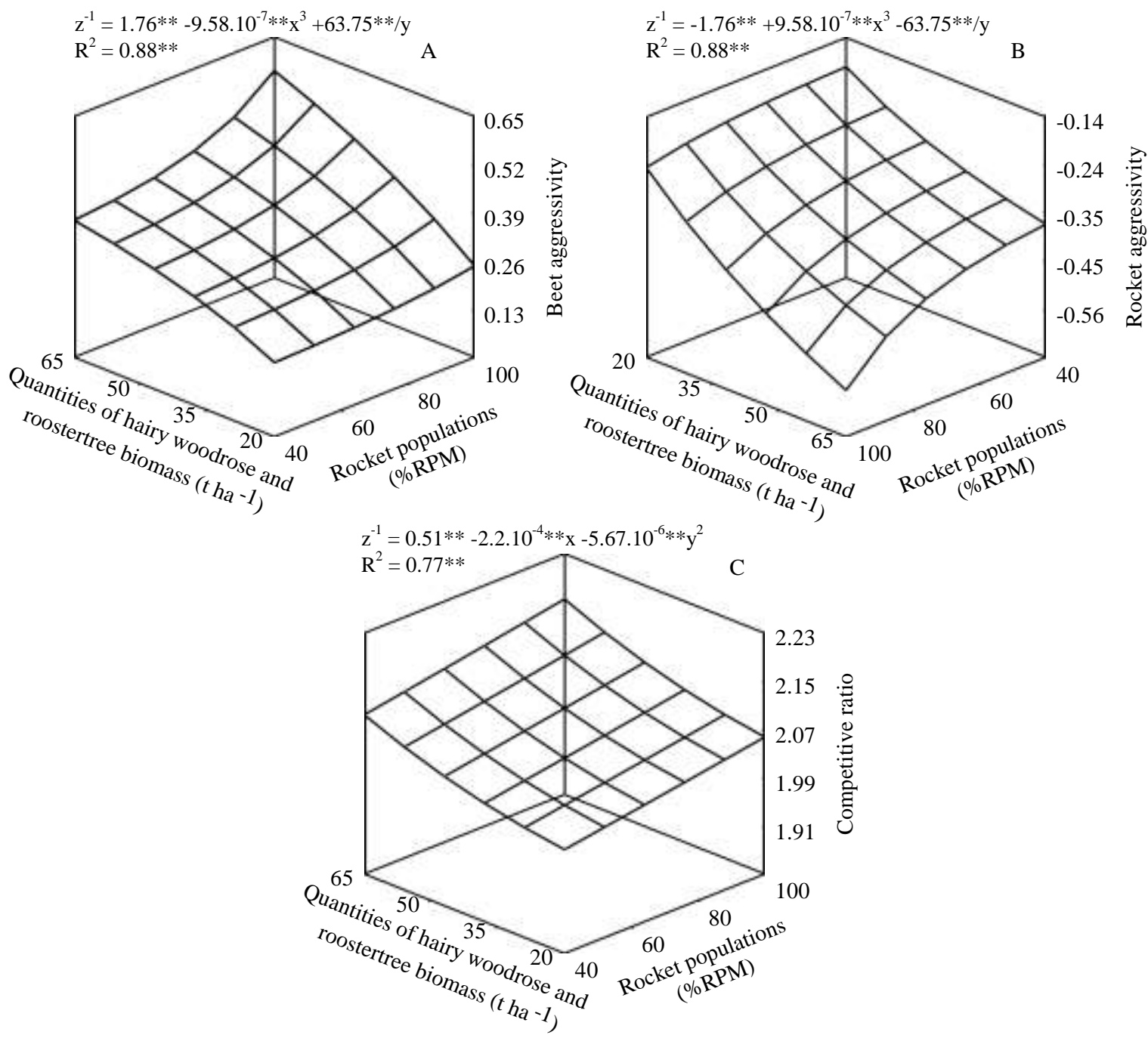

Source: Authors

Regarding crops competitive relationships, the maximum values obtained in the respective balanced quantities of hairy woodrose and roostertree biomass and rocket plant populations show the most efficient use of ambient resources such as water, solar radiation and nutrients (Nunes et al., 2018). These maximum points also express the adequate competitiveness degree between crops, showing how many times the dominant culture was competitively superior to the dominated culture.

The maximum value obtained for competitive ratio was 2.15 in the biomass balanced quantity of $65 \mathrm{t} \mathrm{ha}^{-1}$ of green fertilizers and the rocket population of 100\% of RPM (Figure 5C). This value was very close to that obtained by Sá et al. (2021), which was 2.75 , in the biomass balanced quantity of $20 \mathrm{t} \mathrm{ha}^{-1}$ of green fertilizers and the rocket population of $40 \%$ of RPM. This index provides the exact degree for the competition, showing how many times the dominant species (beet) is more competitive than the dominated species (rocket). Thus, in intercropping system, the crop with the greatest competitive ratio makes better use of ambient resources.

On the other hand, the aggressivity of beet can also be attributed to factors related to morphology, physiology and nutritional needs of the crop. According to Passos et al. (2019), the crops competitiveness is proportional to the increase of plant 
population in planted area. Thus, with the increase in the rocket population and increase in the balanced quantity of green fertilizers, it was observed that the rocket competitive capacity decreased and that of beet crop increased

\subsection{Economic indicators}

For the economic indices: gross return (GI), net return (NI), rate of return (RR) and profit margin were not observed no significant interaction among the treatment-factors (Table 3).

Table 3. F values for gross return (GR) net return (NR), rate of return (RR) and profit margin (PM) of beet intercropped with rocket under balanced quantities of hairy woodrose and roostertree biomass and rocket plant populations.

\begin{tabular}{lccccc}
\hline \multicolumn{1}{c}{ Sources of variation } & GL & GR & NR & RR & PM \\
\hline Blocks & 3 & $0.81^{\text {ns }}$ & $0.81^{\text {ns }}$ & $0.69^{\text {ns }}$ & $0.21^{\text {ns }}$ \\
Quantities of hairy woodrose and & 3 & $16.14^{* *}$ & $15.01^{* *}$ & $12.12^{* *}$ & $10.78^{* *}$ \\
roostertree biomass (Q) & & & & & \\
Rocket population (P) & 3 & $92.47^{* *}$ & $75.88^{* *}$ & $42.24^{* *}$ & $43.05^{* *}$ \\
Q x P & 9 & $1.33^{\text {ns }}$ & $1.33^{\text {ns }}$ & $1.33^{\text {ns }}$ & $1.23^{\text {ns }}$ \\
\hline CV $(\%)$ & 7.84 & 10.82 & 8.00 & 3.52 \\
\hline
\end{tabular}

$* *=\mathrm{P}<0.01 ; \mathrm{ns}=\mathrm{P}>0.05$. Source: Authors

Nevertheless, response surfaces were adjusted for GR, NR, RR and PM in function of treatment-factors, showing the highest values of $85,827.79$ and $65,425.01 \mathrm{R} \$ \mathrm{ha}^{-1}$ for gross and net returns, of $\mathrm{R} \$ 4.24$ for each real invested and $77.02 \%$ of profit margin reached in the biomass balanced quantity of $65 \mathrm{t} \mathrm{ha}^{-1}$ of the green fertilizers and rocket population of $100 \%$ of the RPM (Figure 6). 
Figure 6. Gross return (A), net return (B), rate of return (C), and profit margin (D) of the beet and rocket intercropping under balanced quantities of hairy woodrose and roostertree biomass and rocket plant populations.
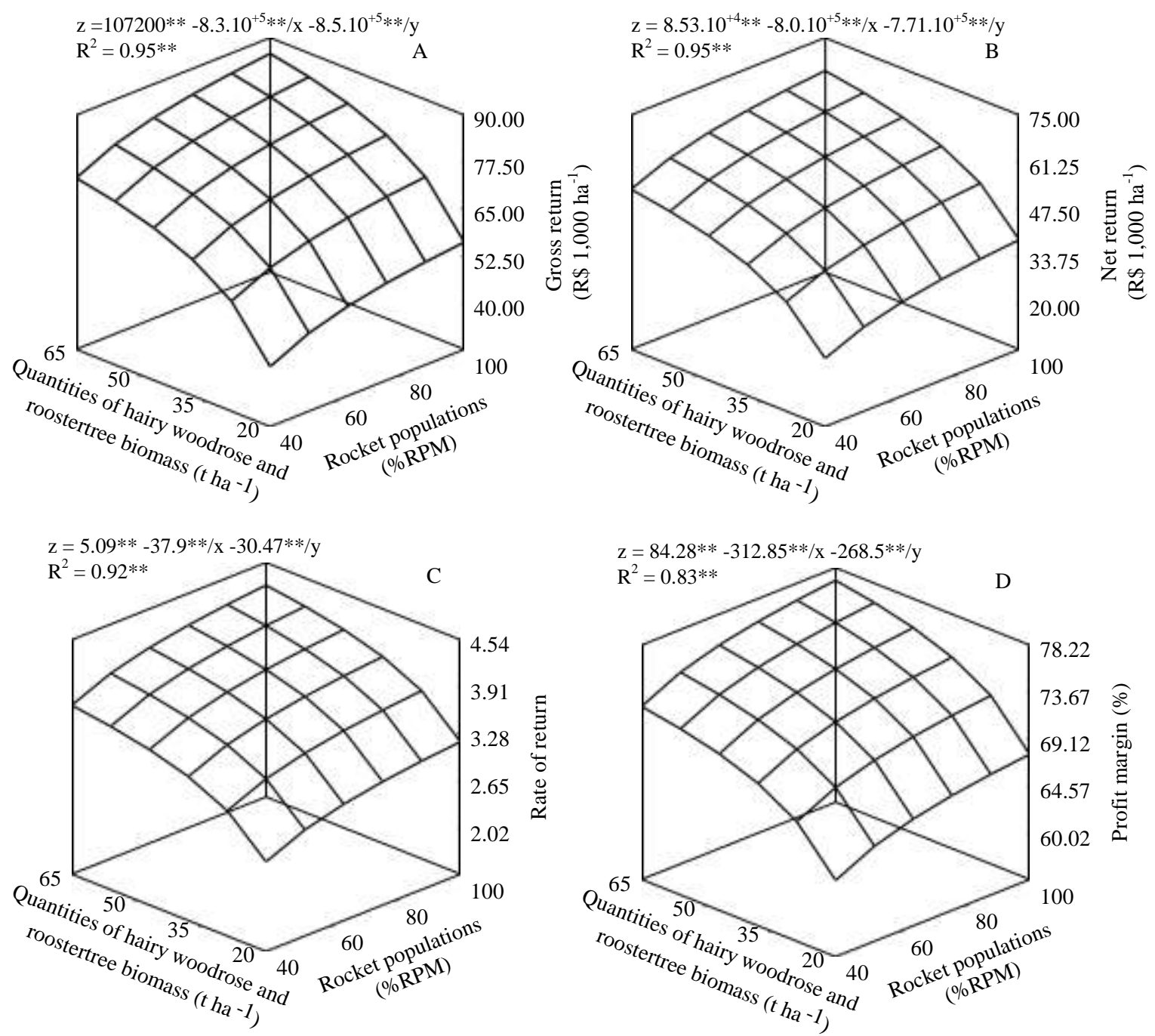

Source: Authors

Economic analysis of intercropped crop production systems generally complements the evaluation of the biological efficacy of these systems, because it takes into account besides the physical production of the system's component cultures, the price of the products based on their commercial classification, product quality and year of cultivation. Gross income is an index that expresses the value of cultures joint production in each associated system, disregarding production costs. It depends exactly on the price at which the system's production is traded. Differently, net return and rate of return are indicators that depend on production costs, as they are standardized in terms of these costs. The higher their values, the greater will be the biological return and the net return showed by the intercropping system, without the production costs.

The results of the economic indices achieved in this work are highly promising in respect of economic advantage for the beet and rocket intercropping, due to net return and rate of return expressed in economic terms, the biological advantages reached in the intercropping under the balanced quantities of hairy woodrose and roostertree biomass and rocket plant populations. These indices indicated that it is advantageous to intercrop beet with rocket, manuring the system organically with green fertilizers of hairy woodrose and roostertree, but adequately managing the rocket population.

The highest economic indices achieved for $\mathrm{GI}=85,827.79$ and $\mathrm{NI}=65,425.01 \mathrm{R} \$ \mathrm{ha}^{-1} ; \mathrm{RR}=\mathrm{R} \$ 4.24$ for each real invested and $\mathrm{PM}=77.02 \%$ of profit margin in this work were higher than those reached by Sá et al. (2021) when intercropped 
the radish tuberose with rocket leafy in the same region of Northeast of Brazil, obtaining the following results: GI $=45,543.92$ and $\mathrm{NI}=24,662.31 \mathrm{R} \$ \mathrm{ha}^{-1} ; \mathrm{RR}=\mathrm{R} \$ 2.20$ for each real invested and $\mathrm{PM}=56.37 \%$ of profit margin, respectively, in the biomass balanced quantity of $65 \mathrm{t} \mathrm{ha}^{-1}$ of the green fertilizers and rocket population of 1000 thousand plants per hectare.

The difference between two researches is in the production costs of treatments tested and the type of tuberose used. In this work, the beet crop was used, while in the other work conducted by Sá et al. (2021) the radish crop was used. The economic indices this work was also superior to those reached by Oliveira et. al. (2017), when they planted rocket and lettuce in association with carrot under different quantities of roostertree biomass and diverse populations of the leafy crops at the same region of this work, where they accomplished the following results: $\mathrm{GI}=34.513 .95 \mathrm{R} \$ \mathrm{ha}^{-1} ; 14,142.68 \mathrm{R} \$ \mathrm{ha}^{-1}$; RR $=\mathrm{R} \$ 1.69$ for each real invested and $\mathrm{PM}=39.39 \%$.

\section{Conclusion}

The intercropping of beet and rocket is highly viable because it presents an agroeconomic and sustainable return when properly manured with biomass of hairy woodrose and roostertree and properly managed in its population density. The highest bio-economic returns of this beet-rocket intercropping were reached with a land equivalent ratio of 1.87, intercropping advantage of 7.44, actual yield loss of 1.90, productive efficiency index of 0.98 , score of the canonical variable of 2.52 , gross return of $85,827.79 \mathrm{R} \$ \mathrm{ha}^{-1}$, net return of $65,425.01 \mathrm{R} \$ \mathrm{ha}^{-1}$, rate of return of $\mathrm{R} \$ 4.24$ for each real invested and a profit margin of $77.02 \%$, respectively, in the biomass balanced quantity of $65 \mathrm{t} \mathrm{ha}^{-1}$ of the green fertilizers and rocket population of 1000 thousand plants per hectare. The hairy woodrose and roostertree biomass use from Caatinga biome proved to be a viable technology for growers who practice the cultivation of beet-rocket strip-intercropping in semi-arid environment. Beet was the dominant culture while the rocket was the dominated culture. This cultivation system should be recommended to family growers who produce leafy and tuberous vegetables in a sustainable form in semi-arid ambient. The LER, IA, AYL, PEI, Z, GI, NI, RR, and PM indices evaluated can help the producer to make adequate decisions in the implementation of his intercropped production system in respect of complementarity and sustainability. For future research with the intercropping of tuberous and leafy vegetables, there is an urgent need to investigate the interactions between the following production factors: green manure, plant population, spatial arrangement of component crops and the establishment of appropriate times for planting crops in the associated system.

\section{Acknowledgments}

We would like to thank the National Council for Scientific and Technological Development (CNPq/Brazil), for the research financial support (process $n^{\circ} 305222 / 2019-8$ ) and for grant number 88887.217232/2018-00 for the doctorate student.

\section{References}

Alvares, C. A., Stape, J. L., Sentelhas, P. C., Gonçalves, J. L. de M., \& Sparovek, G. (2014). Koppen's climate classification map for Brazil. Meteorologische Zeitschrift, 22 (6), 711-728. 10.1127/0941-2948/2013/0507

Andrade Filho, F. C., Oliveira, E. Q., Lima, J. S. S., Moreira, J. N., Silva, I. N., Lins, H. A., Cecílio Filho, A. B., Barros Junior, A. P., \& Bezerra Neto, F. (2020). Agro-economic viability from two croppings of broadleaf vegetables intercropped with beet fertilized with roostertree in different population densities. Revista de la Facultad de Ciencias Agrarias, 52 (1), 210-224.

Batista, M. A. V., Bezerra Neto, F., Silva, M. L., Ambrósio, M. M. Q., \& Cunha, J. L. X. L. (2016). Atributos de solo-planta e de produção de beterraba influenciados pela adubação com espécies da Caatinga. Horticultura Brasileira, 34 (1), 31-38. 10.1590/S0102-053620160000100005

Bezerra Neto, F., Gomes, E. G., Araújo, R. R. de, Oliveira, E. Q. de, Nunes, G. H. de S., Grangeiro, L. C., \& Azevedo, C. M. da S. B (2010). Evaluation of yield advantage indexes in carrot-lettuce intercropping systems. Interciencia, 35(1), 59-64.

Bhatt, B. K. (2011). Statistical evaluation for analysing intercropping experiments. Lexington, KY: LAP LAMBERT Academic Publishing. 93p.

Cecílio Filho, A. B., Bezerra Neto, F., Rezende, B. L. A., Barros Júnior, A. P., \& Lima, J. S. S. (2015). Indices of bio-agroeconomic efficiency in intercropping systems of cucumber and lettuce in greenhouse. Australian Journal of Crop Science, 9(12), 1154-1164. 
Chaves, A. P., Bezerra Neto, F., Lima, J. S. S., Silva, J. N., Nunes, R. L. C., Barros Júnior, A. P., Lima, G. K. L., \& Santos, E. C. (2020). Cowpea and beet intercropping agro-economic dynamics under spatial arrangement and cowpea population density. Horticultura Brasileira, 38 (2), 192-203. 10.1590/s0102053620200212

Dhima, K. V., Lithourgidis, A. S., Vasilakoglou, I. B., \& Dordas, C. A. (2007). Competition indices of common vetch and cereal intercrops in two seeding ratio. Field Crops Research, 100 (2/3), 249-256. 10.1016/j.fcr.2006.07.008

Ferreira, D. F. (2011). Sisvar: a computer statistical analysis system. Ciência e Agrotecnologia, 35 (6), 1039-1042. 10.1590/S1413-70542011000600001

Gebru, H. (2015). A review on the comparative advantages of intercropping to mono-cropping system. Journal of Biology, Agriculture and Healthcare, 5(9), 113.

Graham M. H., \& Haines R. J. (2006). Organic matter status and the size, activity and metabolic diversity of the soil microbial community in the row and interrow of sugar cane under burning a trash retention. Soil Biology \& Biochemistry, 38(1), 21-31. 10.1016/j.soilbio.2005.04.011

Grangeiro, L. C., Bezerra Neto, F., Negreiros, M. Z., Cecílio Filho, A. B., Caldas, A. V. C. E., \& Costa, N. L. (2007). Produtividade da beterraba e rúcula em função da época de plantio em monocultivo e consórcio. Horticultura Brasileira, 25(4), 571-575. 10.1590/S0102-05362007000400016

Guerra, N. M., Bezerra Neto, F., Lima, J. S. S., Santos, E. C., Nunes, R. L. C., Porto, V. C. N., Queiroga, R. C. F., Lino, V. A. S., \& Sá, J. M. (2021). Productive and agro-economic benefits in beet-lettuce intercropping under organic manuring and population densities. Research, Society and Development, 10(4), 1-25. $10.33448 /$ rsd-v10i4.13883

INMET - Instituto Nacional de Meteorologia. (2019). Dados meteorológicos. Brasilia: Ministério da Agricultura, Pecuária e Abastecimento, Disponível em: https://portal.inmet.gov.br.

Lima, V. I. A. de, Lima, J. S. S. de, Bezerra Neto, F., Santos, E. C. dos, Rodrigues, G. S. de O., \& Paula, V. F. S. de. (2014). Viabilidade agroeconômica do cultivo consorciado de coentro, alface e rúcula sob diferentes arranjos espaciais. Enciclopédia Biosfera, 10(18), 3060-3065.

Meira, A. L., Leite, C. D., \& Moreira, V. R. R. (2012). Plantas companheiras. São Paulo: Coordenação de Agroecologia - Ministério da Agricultura, Pecuária e Abastecimento.

Nunes, R. L. C., Bezerra Neto, F., Lima, J. S. S., Barros Júnior, A. P., Chaves, A. P., Silva, J. N. (2018). Agro-economic responsiveness of radish associations with cowpea in the presence of different amounts of Calotropis procera, spatial arrangements and agricultural crops. Ciência e Agrotecnologia, 42(4), 350-364. 10.1590/1413-70542018424010318

Oliveira, L. A. A., Bezerra Neto, F., Barros Junior, A. P., Silva, M. L. Oliveira, O. F. N., \& Lima, J. S. S. (2017). Agro-economic efficiency of polycultures of arugula-carrot-lettuce fertilized with roostertree at different population density proportions. Revista Brasileira de Engenharia Agrícola e Ambiental, 21(11), 791-797. 10.1590/1807-1929/agriambi.v21n11p791-797

Oliveira Neto, D. H., Carvalho, D. F., Silva, L. D. B., Guerra, J. G. M., \& Ceddia, M. B. (2011). Evapotranspiração e coeficientes de cultivo da beterraba orgânica sob cobertura morta de leguminosa e gramínea. Horticultura Brasileira, 29 (3), 330-334. 10.1590/S0102-05362011000300012

Oseni, T. O. (2010). Evaluation of sorghum-cowpea intercrop productivity in savanna agro-ecology using competition indices. Journal of Agricultural Science, 2(3), 230-234. 10.5539/jas.v2n3p229

Passos, F. D. A, Nunes, J., Boiago, N. P., Zanatta, F. S., Correa Junior, E. O., Araújo, L. R. V., Silveira, H. T. N., \& Lima, G. B. (2019). Produtividade de milho em diferentes populações de plantio. Revista Cultivando o Saber, 12, 1-11.

Pinto, C. M., Sizenando Filho. F. A., Cysne, J. R. B., \& Pitombeira, J. B. (2011). Produtividade e índices competição da mamona consorciada com gergelim, algodão, milho e feijão caupi. Revista Verde, 6(2), 75-85.

Ribeiro, G. M., Bezerra Neto, F., Lima, J. S. S., Silva, M. L., Barros Júnior, A. P., \& Santos, E. C. (2017). Agro-economic efficiency of the intercropping of carrot x cowpea-vegetable under different spatial arrangements and population densities. Revista Caatinga, 30(4), 847-854. 10.1590/1983-21252017 v30n404rc

Sá, J. M., Bezerra Neto, F., Queiroga, R. C. F., Chaves, A. P., Lima, J. S. S., Santos, E. C., Nunes, R. L. C., Guerra, N. M., Porto, V. C. N., Lino, V. A. S., \& Gomes, C. D. L. (2021). Agro-economic efficiency in radish-arugula intercropping as a function of green manuring and population density. Research, Society and Development, 10 (5), 1-21. 10.33448/rsd-v10i5.14867

Santos, H. G., Jacomine, P. K. T., Anjos, L. H. C., Oliveira, V. A., Lumbreras, J. F., Coelho, M. R., \& Cunha, T. J. F. (2018). Sistema brasileiro de classificação de solos. Brasília: Embrapa. 356 p.

Silva, M. G., Sharma, R. D., Junqueira, A. M. R., \& Oliveira, C. M. (2006). Efeito da solarização, adubação química e orgânica no controle de nematoides em alface sob cultivo protegido. Horticultura Brasileira, 24(4), 489-494. 10.1590/S0102-05362006000400019

Silva, I. N., Bezerra Neto, F., Barros Júnior, A. P., Lima, J. S. S., Batista, T. M. V., \& Lins, H. A. (2018a). Green manure and spatial arrangement in the sustainability improvement of lettuce-beet intercrops. Revista Brasileira de Engenharia Agrícola e Ambiental, 22(7), 451-457. 10.1590/1807-1929/ agriambi.v22n7p451-457

Silva, M. L., Bezerra Neto, F., Linhares, P. C. F., Sá, J. R., Lima, J. S. S., \& Barros Júnior, A. P. (2011). Produção de beterraba fertilizada com jitirana em diferentes doses e tempos de incorporação ao solo. Revista Brasileira de Engenharia Agrícola e Ambiental, 15 (8), 801-809. 10.1590/S1415-43662011 000800006 
Research, Society and Development, v. 10, n. 8, e20910817112, 2021

(CC BY 4.0) | ISSN 2525-3409 | DOI: http://dx.doi.org/10.33448/rsd-v10i8.17112

Silva, A. F. A. da, Souza, E. G. F., Santos, M. G. dos, Barros Júnior, A. P., Bezerra Neto, F., \& Silveira, L. M. da. (2015). Rentabilidade do rabanete adubado com flor-de-seda em duas épocas de cultivo no semiárido de Pernambuco. Amazonian Journal of Agricultural and Environmental Sciences, 58(2), 198-207. $10.4322 /$ rca. 1761

Silva, I. N., Bezerra Neto, F., Barros Júnior, A. P., Lima, J. S. S., Chaves, A. P., Albuquerque, J. R. T., Lins, H. A., Santos, M. G., \& Soares, E. B. (2018b). Agronomic performance and economic profitability of lettuce fertilized with Calotropis procera as a green manure in a single crop. Australian Journal of Crop Science 12(10), 1573-1577. 10.21475/ajcs.18.12.10.p1114

Silva, J. N., Bezerra Neto, F., Lima, J. S. S., Rodrigues, G. S. O., Barros Júnior, A. P., \& Chaves, A. P. (2017). Combinations of coriander and salad rocket cultivars in bicropping systems intercropped with carrot cultivars. Revista Caatinga, 30(1), 125-135. 10.1590/1983-21252017v30n114rc

Silva, J. N., Bezerra Neto, F., Lima, J. S. S., Chaves, A. P., Santos, E. C., \& Nunes, R. L. C. (2021). Agro-economic indicators for carrot under green manure in a semi-arid environment. Revista Caatinga, 34(2), 257-265. 10.1590/1983-21252021v34n202rc

Sousa, D. M., Bezerra Neto, F., Lima, J. S. S., Lima, G. K. L., Chaves, A. P., \& Silva, J. N. A. (2018). Agro-economic performance of the association of beet with green cowpea in different amounts of hairy woodrose. Revista Brasileira de Engenharia Agrícola e Ambiental, 22(3), 194-199. 10.1590/1807-1929/ agriambi.v22n3p194-199

Systat Software Inc. 2021. Table curve 3D Academic Edition. Systat Software Inc.

Strassburger, A. S., Peil, R. M. N., Schwengber, J. E., Medeiros, C. A. B., Martins, D. S., \& Silva, J. B. (2010). Crescimento e produtividade de cultivares de morangueiro de "dia neutro" em diferentes densidades de plantio em sistema de cultivo orgânico. Revista Bragantia 69(3), 623-630. 10.1590/S0006-8705 2010000300014 